DEPARTMENT OF THE INTERIOR

UNITED STATES GEOLOGICAL SURVEY

\title{
GEOLOGIC MAP OF THE BUCARAMANGA QUADRANGLE (H-12), COLOMBIA
}

By Dwight E. Ward and Richard Goldsmith, (USGS), and Andrés Jimeno, V., Jaime Cruz B., Hernán Restrepo, and Eduardo Gómez R., (Inst. Nacional de Investigaciones Geológico-Mineras)

Prepared in cooperation with the INSTITUTO NACIONAL DE INVESTIGACIONES GEOLOGICO-MINERAS '

MINISTERIO DE MINAS Y PETROLEOS, COLOMBIA

under the auspices of the

GOVERNMENT OF COLOMBIA

and the

AGENCY FOR INTERNATIONAL DEVELOPMENT

U.S. DEPARTMENT OF STATE 


\section{GEOLOGIC MAP SYMBOLS \\ COMMONLY USED ON MAPS OF THE UNITED STATES GEOLOGICAL SURVEY (Special symbols are shown in explanation)}

Contact-Dashed where approximately located; short dashed where inferred; dotted where concealed

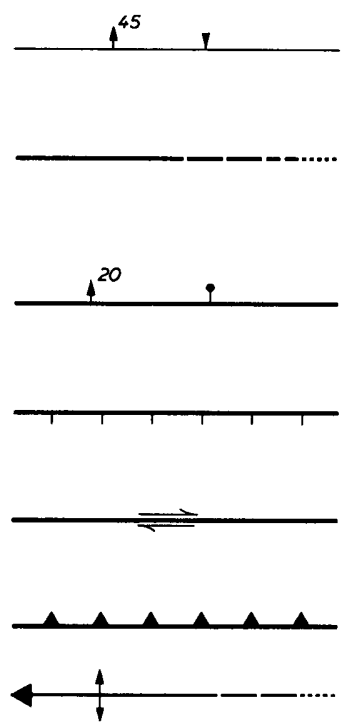

Contact-Showing dip; well exposed at triangle

Fault-Dashed where approximately located; short dashed where inferred; dotted where concealed

Fault, showing dip-Ball and bar on downthrown side

Normal fault-Hachured on downthrown side

Fault-Showing relative horizontal movement

Thrust fault-Sawteeth on upper plate

Anticline-Showing direction of plunge; dashed where approximately located; dotted where concealed

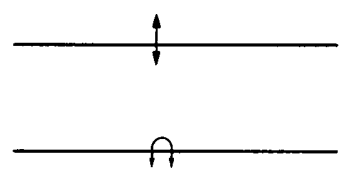

Asymmetric anticline-Short arrow indicates steeper limb

Overturned anticline-Showing direction of dip of limbs

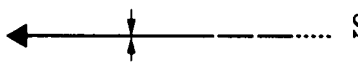

Syncline-Showing direction of plunge; dashed where approximately located; dotted where concealed

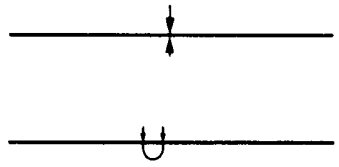

Asymmetric syncline--Short arrow indicates steeper limb

Overturned syncline-Showing direction of dip of limbs

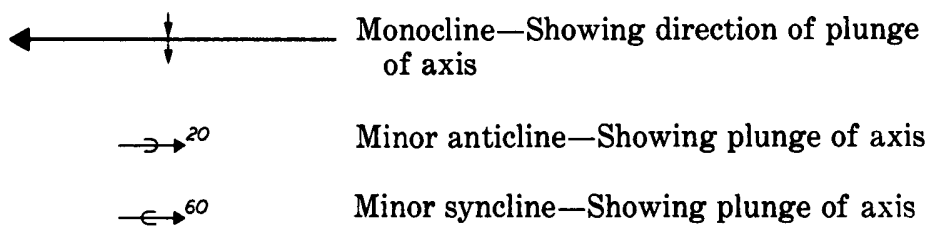

Strike and dip of beds-Ball indicates top of beds known from sedimentary structures

곤 Inclined $\oplus$ Horizontal

+ Vertical 40 Overturned

Strike and dip of foliation

20. Inclined $\rightarrow$ Vertical $\rightarrow$ Horizontal

Strike and dip of cleavage

15 Inclined $\longmapsto$ Vertical $†$ Horizontal

Bearing and plunge of lineation

15 _ Inclined - Vertical $\longrightarrow$ Horizontal

Strike and dip of joints

40 Inclined $\rightarrow$ Vertical $\rightarrow$ Horizontal

Note: Planar symbols (strike and dip of beds, foliation or schistosity, and cleavage) may be combined with linear symbols to record data observed at same locality by superimposed symbols at point of observation. Coexisting planar symbols are shown intersecting at point of observation.

\section{Shafts}

$\square$ Vertical $\square$ Inclined

Adit, tunnel, or slope

$\succ$ Accessible $\succ$ Inaccessible

$X$ Prospect

Quarry

Active Abandoned

Gravel pit

$X$ Active $\quad \mp$ Abandoned

Oil wells

$\circ$ Drilling $\phi$ Shut-in $-\phi$ - Dry hole,

Gas Show of gas abandoned

- Oil Show of oil 